\title{
The Effectiveness of Siwak (Salvadora Persica) Fibrous Chewing Gum Against the Amount of Bacteria in Saliva
}

\author{
$1^{\text {st }}$ Sri Wahyuni \\ Dental Nursing \\ Poltekkes Kemenkes Palembang \\ Palembang, Indonesia \\ drgsriwahyuni676@gmail.com
}

\author{
$2^{\text {nd }}$ RA Zainur \\ Dental Nursing \\ Poltekkes Kemenkes Palembang \\ Palembang, Indonesia \\ zainur@poltekkespalembang.ac.id
}

\author{
$3^{\text {rd }}$ Tris syahniati \\ Dental Nursing \\ Poltekkes Kemenkes Palembang \\ Palembang, Indonesia \\ trisyahniati@poltekkespalembang.ac.id
}

Corresponding author : trisyahniati@poltekkespalembang.ac.id

\begin{abstract}
Saliva is a liquid in the oral cavity which is very important, especially related to the formation of caries, because of its role which affects the growth of plaque in the mouth. Benefits of chewing gum is to prevent cavities, to prevent halitosis and to improve brain function by increasing blood flow to the brain so that the brain can works optimally. The aim of this research is to measure the effectiveness of siwak fibrous chewing gum on the number of bacteria in saliva. The benefits of replacing a toothbrush when it is not possible to brush the teeath. Type of this research was experimental research with pre and post test design in October 2019. Research was conducted at SMP N 18 Palembang and examination of the number of bacteria in the Central Laboratory of Health Laboratory (BBLK) with the number of samples 52 people divided into 4 groups of 13 groups respectively. The result showed a significant difference in the number of bacteria after chewing candy fibrous siwak 0.25 grams, 0.5 grams and 1 gram. Plaque score decreased after consuming Siwak fibrous gum. The most effective way to reduce the amount of bacteria in saliva and plaque score is siwak1 gram of fibrous gum.
\end{abstract}

Keywords: siwak fibrous gum, bacteria and plaque.

\section{INTRODUCTION}

Basic Health Research (Riskesdas) in 2018 was stated that dental and mouth problems in Indonesian society experienced a significant increase from $23.9 \%$ to $57.6 \%$. While in South Sumatra the prevalence of caries was $51.0 \%$ and those with caries experience were equal to $71.2 \%$. Saliva is a liquid in the oral cavity which is very important, especially related to the formation of caries, because of its role which affects the growth of plaque in the mouth. Saliva can neutralize an overly acidic state of the mouth and form a thin layer to prevent contact between the oral bacteria and the gingiva and teeth. The benefits of chewing gum, which is to prevent cavities, to prevent halitosis and to improve brain function by increasing blood flow to the brain so that the brain can works optimally. Siwak is a plant with salvadoraceae which is usually used by Muslims to clean teeth [1]. Some researchers report the presence of the antibacterial effect of siwak on cariogenic bacteria and periodontal pathogens specifically species of bacteroides and inhibit plaque formation [2]. Siwak contains salvadorine which has an anti-bacterial effect [3]. Siwak also has a mechanical effect from its siwak fiber [4]. The problem is how to clean teeth and mouth when it is not possible to brush the teeth. The aim of the research is to provide an alternative method that can be used to maintain healthy teeth and mouth when it is not possible to brush teeth with toothpaste by chewing gum containing siwak fiber.

\section{METHOD}

The type of this research was experimental research with pre and post test design. The study was conducted in March October 2019. The research site was at SMP N 18 Palembang and examination of the number of bacteria at the Central Laboratory of Health (BBLK). The technique used was purposive sampling and the number of samples with a correlative analytical formula. With a total sample of 52 people divided by 4 groups into 13 groups each. The process of taking saliva by spitting method, namely by means of research subjects were asked to chew siwak fibrous gum 2 times a day for 7 days, then subjects were asked to collect saliva for 5 minutes and put into a sterile pot that has been provided. Furthermore, saliva is sent to the Central Laboratory of Health Laboratory (BBLK) to count the number of bacteria in the saliva. The data normality test used is the Shapiro-Wilk test with normally distributed 
data so that it uses Parametric Analysis, Anova, followed by the Lavene statistical homogeneity test and Post hoc test.

\section{RESULTS}

Table 1. Average bacterial differences before and after chewing on siwak fibrous gum

\begin{tabular}{|c|c|c|c|c|}
\hline Group: & Mean & SD & $95 \% \mathrm{CI}$ & $P$ value \\
\hline $\begin{array}{l}\text { Control } \\
\text { (xylitol gum) }\end{array}$ & 1,125 & 3,72 & $39,55-44,255$ & \multirow{4}{*}{0,001} \\
\hline $\begin{array}{l}\text { Chewing gum } \\
\text { with Siwak } \\
0.25 \text { gram }\end{array}$ & 2,230 & 3,29 & $78,445-82,631$ & \\
\hline $\begin{array}{l}\text { Chewing gum } \\
\text { with Siwak } 0.5 \\
\text { gram }\end{array}$ & 4,188 & 5,96 & $108,768-116,351$ & \\
\hline $\begin{array}{l}\text { Chewing gum } \\
\text { with Siwak } 1 \\
\text { gram }\end{array}$ & 8,053 & $\begin{array}{c}22,4 \\
6\end{array}$ & $208,738-237,291$ & \\
\hline
\end{tabular}

*uji one way anova

Based on table 1 the results of the study the number of bacteria present in saliva before and after chewing gum there was a significant difference in $p<0.001$ the difference in the number of bacteria before chewing gum and after chewing gum was the highest with 1 gram siwak fiber, and the lowest in the control group.

Table 2. Results of Post Hoc Test Analysis Tests for differences in the number of chewing bacteria Chewing Gum Combination of Miswak Fiber (Salvadora Persica)

\begin{tabular}{|c|c|c|c|c|}
\hline \multirow[b]{2}{*}{ (I) Group } & \multirow[b]{2}{*}{ (J) Group } & \multirow[b]{2}{*}{ Sig. } & \multicolumn{2}{|c|}{ 95\% Confidence Interval } \\
\hline & & & $\begin{array}{l}\text { Lower } \\
\text { Bound }\end{array}$ & $\begin{array}{l}\text { Upper } \\
\text { Bound }\end{array}$ \\
\hline \multirow[t]{3}{*}{ Control } & siwak 1 gram & .000 & -194.53749 & -167.72151 \\
\hline & siwak 0.25 gram & .000 & -52.06141 & -25.24542 \\
\hline & siwak 0.5 gram & .000 & -84.08249 & -57.26651 \\
\hline \multirow{3}{*}{$\begin{array}{l}\text { siwak } 1 \\
\text { gram }\end{array}$} & Control & .000 & 167.72151 & 194.53749 \\
\hline & siwak 0.25 gram & .000 & 129.06809 & 155.88408 \\
\hline & siwak 0.5 gram & .000 & 97.04701 & 123.86299 \\
\hline \multirow{3}{*}{$\begin{array}{l}\text { siwak } 0.25 \\
\text { gram }\end{array}$} & Control & .000 & 25.24542 & 52.06141 \\
\hline & siwak 1 gram & .000 & -155.88408 & -129.06809 \\
\hline & siwak 0.5 gram & .000 & -45.42908 & -18.61309 \\
\hline \multirow{3}{*}{$\begin{array}{l}\text { siwak } 0.5 \\
\text { gram }\end{array}$} & Control & .000 & 57.26651 & 84.08249 \\
\hline & siwak 1 gram & .000 & -123.86299 & -97.04701 \\
\hline & siwak 0.25 gram & .000 & 18.61309 & 45.42908 \\
\hline
\end{tabular}

There was a significant difference in the number of bacteria before and after chewing siwak fibrous gum and there was a significant difference in the number of bekteri in saliva between chewing siwak fibrous gum 0.25 grams, 0.5 grams and 1 gram.
Table 3. Average plaque differences before and after chewing with siwak fibrous gum

\begin{tabular}{lcccc}
\hline \multicolumn{1}{c}{ Group: } & Mean & SD & $95 \%$ CI & P value* \\
\cline { 1 - 4 } $\begin{array}{l}\text { Control (xylitol } \\
\text { Gum) }\end{array}$ & 9,75 & 2,454 & $8,19-11,31$ & \\
\cline { 1 - 3 } $\begin{array}{l}\text { Chewing gum } \\
\text { with Siwak 0,25 } \\
\text { gram }\end{array}$ & 16,75 & 4,515 & $13,88-19,62$ & \\
\cline { 1 - 2 } $\begin{array}{l}\text { Chewing gum } \\
\text { with Siwak 0,5 } \\
\text { gram }\end{array}$ & 23,42 & 7,012 & $18,96-27,87$ & \\
\hline $\begin{array}{l}\text { Chewing gum } \\
\text { with Siwak 1 } \\
\text { gram }\end{array}$ & 36,42 & 19,271 & $24,17-48,66$ & \\
\hline
\end{tabular}

*uji One Way anova

Based on table 3, it is found that the average difference between plaque according to groups there is a significant difference with $\mathrm{P}$ value of 0.001 . Difference in the amount of plaque before chewing gum and after chewing gum was highest in the gum group with sigram fiber 1 gram, and lowest in the control group.

Table 4. Analysis Results Post Hoc Test Test differences in chewing plaque scores Chewing Gum Combination of Miswak

\begin{tabular}{|c|c|c|c|c|}
\hline \multirow{2}{*}{ I) Group } & \multirow{2}{*}{ (J) Group } & \multirow{2}{*}{ Sig. } & \multicolumn{2}{|c|}{$\begin{array}{c}95 \% \text { Confidence } \\
\text { Interval }\end{array}$} \\
\hline & & & $\begin{array}{l}\text { Lower } \\
\text { Bound }\end{array}$ & $\begin{array}{l}\text { Upper } \\
\text { Bound }\end{array}$ \\
\hline \multirow[t]{3}{*}{ Control } & siwak 1 gram & .000 & -38.59 & -14.74 \\
\hline & siwak 0.25 gram & .000 & -18.92 & 4.92 \\
\hline & siwak 0.5 gram & .000 & -25.59 & -1.74 \\
\hline \multirow[t]{3}{*}{ siwak 1 gram } & Control & .000 & 14.74 & 38.59 \\
\hline & siwak 0.25 gram & .000 & 7.74 & 31.59 \\
\hline & siwak 0.5 gram & .000 & 1.08 & 24.92 \\
\hline \multirow{3}{*}{$\begin{array}{l}\text { siwak } 0.25 \\
\text { gram }\end{array}$} & Control & .000 & -4.92 & 18.92 \\
\hline & siwak 1 gram & .000 & -31.59 & -7.74 \\
\hline & siwak 0.5 gram & .000 & -18.59 & 5.26 \\
\hline \multirow[t]{3}{*}{ siwak 0.5 gram } & Control & .000 & 1.74 & 25.59 \\
\hline & siwak 1 gram & .000 & -24.92 & -1.08 \\
\hline & siwak 0.25 gram & .000 & -5.26 & 18.59 \\
\hline
\end{tabular}

There was a significant difference in plaque score before and after chewing on siwak fibrous gum and there was a significant difference in plaque score between chewing on siwak fibrous gum with 0.25 gram, 0.5 gram and 1 gram. 


\section{DISCUSSION}

A. Effectiveness of siwak fibrous gum chewing on the number of bacteria

The control group and the treatment group chewing siwak fibrous gum decreased in the number of bacteria, because the control group using xylitol. The content of xylitol in the gum has the benefit of suppressing the number of Streptococcus mutans bacteria as one of the germs that caused dental caries [5].

Chewing gum has several advantages because of the fiber-based content will result in tooth cleansing (self cleansing effect), because when chewing, there will be a shift in the fibers so that it can releases food debris attached to the tooth surface by mastication will stimulate saliva secretion [6]. In saliva there are various kinds of enzymes, one of which is mucine, zidene and lysozyme which have bacteriostatic properties which can make some oral bacteria become inactive [7]. Siwak activity in reducing SCN which when reacting with sulfhodrol groups in bacterial enzymes will cause bacterial death [4].

\section{B. Effectiveness of siwak fibrous gum chewing on the amount of plaque}

Siwak is a plant with salvadoraceae which is usually used by Muslims to clean teeth [1]. Some researchers report the anti-bacterial effect of siwak on cariogenic bacteria and periodontal pathogens, and inhibit the formation of plaques [2], [8], [9]. Rasulullah SAW said: "Siwak can clean the mouth and bring the pleasure of Allah [10]. Special ingredients contained in chewing gum such as enzymes and bicarbonate can help prevent the formation of bacteria in plaque. The presence of saliva flow also helps reduce sediment leftovers and reduce bacterial populations [11] Children's plaque can decrease significantly if they consumed chewing sugar-free gum [12], [13].

\section{CONCLUSION}

1. There is a significant difference in the number of bacteria in saliva that chews siwak fibrous gum (Salvadora Persica) 0.25 gram, 0.5 gram, and 1 gram $P$ Value $<0.001$

2. There is a significant difference in the score of siwak fibrous chewing gum (Salvadora Persica) chewing plaque score 0.25 gram, 0.5 gram and 1 gram $P$ Value $<0.001$
3. Siwak fibrous gum 1 gram is effective in reducing the amount of bacteria in saliva and decreasing plaque score.

\section{ACKNOWLEDGMENT}

This research was funded by the Palembang Health Ministry of Health Polytechnic in 2019. Thanks and appreciation were given to the Palembang Health Polytechnic Director and students of Junior High School 18 Palembang.

\section{REFERENCES}

[1] Salehi P, Momeni Danaie S. Comparison of the antibacterial effects of persica mouthwash with chlorhexidine on streptococcus mutans in orthodontic patients. Daru 2006;14:178-82.

[2] Zaenab, Mardiastuti H, VP A, B L. Uji Antibakteri Siwak (Salvadora Persica Linn.) Terhadap Streptococcus Mutans (Atc31987) dan Bacteroides melaninogenicus. Makara Kesehat 2004;8:37-40.

[3] Al-Dabbagh SA, Qasim HJ, Al-Derzi NA. Miswak as an Alternative to the Modern Toothbrush in Preventing Oral Diseases. Int J Dent Hyg 2016;15:1-34.

[4] Darout IA, Christy AA, Skaug N, Egeberg PK. Identification and quantification of some potentially antimicrobial anionic components in miswak extract. Indian $\mathrm{J}$ Pharmacol 2000;32:11-4

[5] Pratiwi R. Perbedaan Daya Hambat terhadap Streptococcus mutans dari Beberapa Pasta Gigi yang Mengandung Herbal. Dent J (Majalah Kedokt Gigi) 2005;38:64-7.

[6] Szöke J, Bánóczy J, Proskin HM. Effect of after-meal sucrose-free gum-chewing on clinical caries. J South African Dent Assoc 2005;60:248-51.

[7] Tarigan R. Karies Gigi. 2nd ed. Jakarta: EGC; 2016.

[8] Almas K, Al-Zeid Z. The Immediate Antimicrobial Effect of a Toothbrush and Miswak on Cariogenic Bacteria: J Contemp Dent Pract 2004;5:1-9.

[9] Ghanadi AR, Davoodi N. Miswak Tree Medicine, Traditional Iranian Medicine and Modern Medicine. J Med Hist 2012;3:119-32.

[10] Khuly SH. Misteri Dasyatnya Gerakan Shalat. Jakarta: Tuhfa Media; 2010.

[11] Damayanti S. Manfaat Permen Karet Bagi Kesehatan 2007. http://www.pdgionline.com/v2/index.php?option=com_conten t\&task=view\&id=212\&Hemid=3 3 .

[12] Hujoel PP, Mäkinen KK, Bennett CA, Isotupa KP, Isokangas PJ, Allen P, et al. The Optimum Time to Initiate Habitual Xylitol Gum-chewing for Obtaining Long-term Caries Prevention. J Dent Res 1999;78:797-803. https://doi.org/10.1177/00220345990780031301.

[13] Tapiainen T. Microbiological effects and clinical use of xylitol in preventing acute otitis media. University of Oulu, 2002. 